
THE

\section{DEVELOPMENT OF SCULPTURE}

\section{A PRELIMINARY PAPER}

BY

J. D. MCGUIRE OF ELLICOTT CITY, MARYLAND

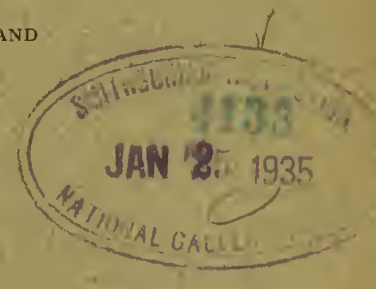

[FROM THE AMERICAN ANTHROPOLOGIST FOR OCTOBER, I894]

WASUINGTON, D. C. JUDD \& DETWYILI:R, PRINTHIS I 894
NMAA/NPG LIBRARY Recataloqued SEP 241090

SMITHSONIAN INSTITUTION 



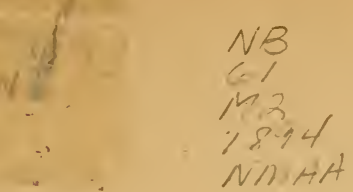

\section{THE DEVELOPIENT OF SCULPTURE.}

BY J. D. MCGUIRE.

The sculptures of ancient Egypt are apparently older than those of any other country. The sculptures of America may be traced to extremely crude beginnings, yet their age is a matter of pure conjecture. So far as one can judge the mechanical execution of the carvings of I'ucatan, for example, there would appear to be a greater similarity between them and the carvings of China than of relationship to Egyptian work. There is such an indivicluality about the sculpture of Egypt and of America and much of that of the Assyrians that one hesitates to attribute to them a common origin.

Marble, now so generally employed in supplying material for statuary, has been used for this purpose probably for the last 2,500 years, yet there are evidences that at a period 2,500 years earlier, the Assyrians and Egyptians made statues which evidenced great artistic ability and mechanical skill, and these statues were made from diorites and syenites, stones harder than marble.

Notwithstanding the many centuries that have elapsed since man first marle sculptures of large size, the alterations in their surfaces have been so slight that we may by comparing them one with another trace the development of the art.

The methorls now employed in producing sculptures and carvings are quite similar, due entirely to mechanical appliances, and are a great improvement over those employed in the production of ancient figures, for it will be seen that carving and sculpture have in their methods of growth approached each other from widely divergent beginnings.

The universal stone celt and the familiar Anerican grooved ax and pestle show in the method of their production the first steps towarl the derelopment of seulpture. Formed to suit the taste of the mechanic making it, the work itself by which it was prorlueerl is not distinguishable from that appearing on all early worked stone. 
The polished surfaces are similar, as were the tools with which the work was performer. Sculpture accompanies a settlerl stage of society. On the other hand, earring is an art commonly found among the most sarage races. The rlevelopment of skill in carring is often encountered in the most unexpecterl bocalities and in places where no evidences are foum of the sculpture of large figures. This difference appears directly traceahle to the morle of life which savagery entails. Wandering during the hunter period from point to point with the change of seasons or as game or fruit became abundant or scarce, with no fixerl ilwellings and with no ability to transport heary statues, there was no incentive to make them. Small carvings of hone, of irory, or of wood appear common to every race. Their small size enabled them to be carried on the person, and an evildence that they were so carried is found in the holes generally bored through them for purposes of suspension.

The apureciation of symmetry of form or of the beauties of color is abundantly evidenced among the earliest traces of man's residence on earth, and is found to exist among all tribes and races of men, if we may judge l,y their implements and their inanufactures.

When man first began to occupy continuously a particular site and to live in settlements, the size of statues, it is found, began to increase, as is evidenced by earrerl posts and woorlen idols.

As settlements became more permanently estal,lisherl ancl more attention was pail to the construction of dwellings, the figures of woorl would give place to the more pretentions, as well as more durable, stone statue, and nowhere is this more markerl than among the ruins of Central and of south America. Among the many things influencing carving, there can be none more important than arailable material for tool-making. To cut diorite or granite successfully requires a tool metal as harl at least as steel, and there is no evidence of such metal possesserl by the early races working such stone. Stone hammers can perform this work with little difficulty, and where statnes of these stomes are found the stone hammer is emmonly met with. A natural inference would be that the hammer was the working tool, certainly until some one may surgest as simple an explanation. 
Nowhere has carving been earried to greater perfection than in the eastern worlil, amd among eastern peoples nome have exeelled the Japanese and (hinese in the skill and artistic eoncept shown in their carvines of ivory and of jaule, as well as of woxt and of serpentine. The early chapters in the history of these carvings are very ancient, and to be fully appreciated should be examined in connection with an acquaintance not only of the physiognomy and costume but of the religions and the mythology of these countries.

Notwithstanding the artistic ability in earving evidenced by the Japanese and the great mechanieal skill shown by the ('hinese, neither nation appears to have been familiar with seulpture; for, although certain of their carvings are colossal, they are but carrings as distinguished from the art of seulpture.

The few statuettes due to Babylonian, Chaldean, Assyrian, or Eyptian workmanship which have been discovered prove abundantly that these nations possessed artisans who were masters of the carver's art. If gaps be found in the development of the sculpture of a nation, in restigation will show them probably to he due rather to some great political change than to a decadence of artistic skill. The gap existing in Egyptian carving and sculpture during several of the dynasties will be found to be due rather to a geographical change of the seat of government than to a decrease of art.

In most countries where sculptures are found it is apparently demonstrable that the method of their production has gone through regular stages of progression from extremely rucle heginningr. It is impossible to prove that seulpture always hegan with the stage of incising outlines into the surfaces of large stones, ats is generally supposed to be the eare.

Conglomerates, the erosion due to the effects of alternate freezing and thawing, the carring done by sand hlown by the wind, or, most common of all, the grincling of the silt held in suspension in water are all known causes of the earving of shapes and outlines, which would appear to afford a more plansible theory conerning the birth of seulpture than floes the theory that seulpture owed its origin te the artificial incision of lines 11 pen reck surfiaces. I few blows giren to a stone, slonperd by any of the processes of mature referred to, womld ilevelop fientres, and would, it is believerl, som learl to a delilerate and intentional shaping of stones. 
That such is the case appears to be shown by the finding of water-washed pelbbles resembling animals or natural implements, often associated with the remains of the earliest periods of hunn existence, especially of those of the caves and shelters which were man's first dwelling places.

The North American Indians appear to have been as ignorant of the seulptor's art as was any race which had learned its first rudiments. Their sculpture appears never to have progressed beyond the production of a rude outline upon some bowlder, which was done by an implement that ate into the stone by a series of continuous blows. Of all the examples known of aboriginal American stone-cutting, it is doubtful whether there is a single one which could be designated even as low relief.

Among the rudest sculptures are to be reckoned the colossal figures found in Easter island, wrought from a coarse basalt or lava, representing the human figure from the waist up. They are shaped by the blows of a stone hammer delivered direetly upon the surface of the stone fashioned. These statues have eyes, nose, mouth, arms, and hands shaped in the most primitive way, with but little regard to anatomical requirements. These statues leave one in serious doubt whether those who made them ever worked outlines as was done by the North American Indians, or imitated wooden figures as the Greeks are by some supposed to have done, or whether they were not rather a development and growth of statuary due to direet imitation of natural forms.

Returning to the American continent, there is found from Mexico far to the southward a remarkable seulptural derelopment, evidenced in monoliths, in slalss carved in low relief, in figures carred in the round, and in mural earvings that are astonishing in their detail and which closely resemble the finish of the most elaborate Chinese work.

The slabs of hasalt or of limestone intended for sculpture were first dressed down to a reasonably smooth surface by a process of hammering with a stone having a rounded edge or by an elongated pointed stone or with a hafted stone celt.

These American earvings or sculptures evidence a skill quite equal to that of the Egyptians of a similar mechanical condition of culture, and often present a distinct individuality.

The Assyrians present a striking instance of national individu- 
ality. The stone used is a grayish alabaster, extremely soft, slalis of which with winged figures carved on them and humanheared bulls of colussal size are common. The incised lines upon these figures show that the work has been done by a cutting process, probably with hafterl tools, although it would be possible to produce the same effect with unhafted stone blades. Alahaster, being almost the only stone in the country, has naturally been the one most used, and its texture measurably influenced the art of Babylonia and of Assyria. To attempt to batter this stone would be to destroy it. The statuary of the most ancient Assyrian period indicates the cutting of diorites as early as 3000 B. C'., as is evideneed by the discovery of two broken statues of this stone covered with euneiform characters of an arehaic type. Much of the technique and general character of these statues would appear to point to a common origin for them with some of those of Egypt.

The derelopment of Egyptian sculpture may be followed with consilerable accuracy through successive stages, beginning with the rudest and ending with the perfect round. Among the oldest efforts at sculpture by the Egyptians are said to be certain incised rocks similar to the stone-euttings of the Ameriean Indians. There are, howerer, some well known carvings of small figures in limestone and in woor found in early Eryptian ruins that are consirlererl to be of an age contemporaneous with primitive sculptures of the Nile valley.

These seulptures maty be tracel through the incised to the low relief, the intaglio, the high relief, the reserverl, the eolosial, and, tinally, the round with considerable accuracy and apprarently in chromological order. On the other hand, the small rule carvings of limestone, succeeded by larger syuatting figures of solicl form, and they in turn displaced by similar figures with more complete forms and increaserl size, until the colossal seated figure is reached, would indicate a possible if not a probable dual origin of the seulptures and carvings of Egypt.

The seals and eylinders of $\Lambda$ ssyria and of Egrypt, of Gireece and of liome, fashiomed by boring and by grinding, present art eras for these conutries deserving of a stuly ly themselves. The carly ligyptian figures appoar to have been produced hy sawing, seraping, and grinding posesses. Tho inciserl and relief seulptures appear to be produced hy the hammer. This tool was 
early used in the statuettes of linestone, of eliorite, and other hard stones, and as late as the reign of the second lammeses.

The archaic statues of the world aprear conmonly to be of hard stones and of tough ones, such as batsilt, diorite, or granite, the surfaces of which could be dressed to any desired form hy a hattering process with a stone held in the hand, which was sul)seruently used for grinding the rough surfaces of the statue. There are drawings of Theban paintings in almost every illustrated work on ancient Egypt representing in minutest detail workmen earying out the processes here sugrested, the practicability of which the author has tested in experimental work.

These paintings do not appear to have been correctly interpreted, nor to have had sufficient eonsideration, judging by the improbable theories allanced by some areheologists to aceount for the methods hy which South American and Egyptian seulprture was done.

The most popular theory to account for the cutting of these hard stones is that early races posiessed the secret of tempering copper until it was suflieiently havel to eut them; others have advaneed the theory of tools suplulied with points and blarles of diamonds. It has even been sugerested that early races could soften stone for a time sufficiently for it to be worked before hardening again. M. Énile Solli, an eminent French author, and himself a gem engraver, surgests that the work on early Eyptian statues was done with the steel pointing tool. Another theory sugrgests that silica eould reduce these statues into form.

The peculiar dress seen on Egyptian statues-having long beards down on the lireast and searlis thrown orer the hearl, the lows joined together, and arms at the side and attached to the body or crossed upon the breast-is often explained by asserting that the posture and dress are due to sacerdotal influences, and that the hard diorites and syenites were selected hy the Egy ptians for their seulptures in order to show that although the nation was in its infaney, it hesitated at no olstacle. Nhout the time of Rameses the second we find that the Egyptians aloandoned the working of diorite and syenite and other hard stones and commenced to work extensively the Theban sandstone. The transition appears suclelen. The surface work on statues appears no longer to be produced by the pitting hammer, but by the chisel blade of metal, probably driven by the mallet, as repre- 
senterl in Theban paintings. The early Cypriotic statuary is of this sandstone, and appears contemporaneous with the later Egyptian art and is probably an outgrowth of it, and marks a step in advance in sculpture. The flat blate of the chisel and the gouge hoth appear to have been in use at this period, as well as the mallet. A close scrutiny, howerer, does not justify the positive assertion that stone touls had gone entirely into disuse, for many of the striations in the tool marks on the cypriotic statues have a more seratehed appearance than would be given by an ordinary chisel or gouge or by a tool of solt metal.

Here we see the old conventional headdress and beard of the Egyptian and the solid and massive figure give way to a free neck. One leg becomes slightly advaneed in front of the other. The legs are no longer attached solidly together; they are slightly cut apart from each other. The arms are bent, with some freedom of action, at the elbow. The hand and wrist stand out a few inches from the body. That this freedom of action is due to the toul rather than to the art stage in which it was produced is evidenced strongly in the elinched fist. Were this freedom of action attempted in the harder stones, or especially in sandstone, with the shaping hammer, the danger of fracture of the arm at the wrist would be very great, and a free round neek would almost inevitably be broken off, because of the absence of the tenon formed of beard and searf. In sculptures of the harder stones, angles are seldom seen; the fingers and toes are of exual length; the surface where cut in for eyes, nose, mouth -in fact, all lines are semicircular depressions due to the round surface of the shaping tool used.

The Thelan saudstones show in a remarkable way the ehange of tool from the hammer to the chisel and mallet, enabling angles to be more readily cut and furrows of any desired depth to be marle. Few examples are known in bigylution art in which seulptures were made of matlile, and when found, the piece of marthe is usually small and finisherl as carving. ('yprus presents few examples of marlule seulptures. Nbout the sixth century li. (C. We first find evidences of skill in marlyle-cutting exhibiterl hy the Cirecks; the harduss of metal al out this period reached a point where the chisel and, alowe all, the prineiple of the file and rasp enablerl marble to le workerl at will, and eon- 
sequently there was no longer any limit to the expression of free action in statuary.

The hammer had become olsolete, the chisel har supplanted it as a shaping tool, and the pointing tool was used with the mallet to cut away the wugh block. There was no comparison between marble, as a medium for the expresion of feeling in art, and any other stone theretofore userl for sculptures. Narble marle perfection prissible in sculpture, the torls of stecl marle the treatment of marble as simple as earving, and thenceforth these two arts, mechanically considered, hecame one.

History does not treat of a time when carring was not, apparently, well known; tradition does not appear to approach much nearer to its genesis. ('arrings were well executed during the period of man's early occupation of the cares of Europe, and most persons who have familiarized themselves with archeological research know the figures of fish or seal engraved on the canine teeth of large carnivora, and the bear, reindeer, musk ox, horse, mammoth, and other animals carved on reindeer horn implements or on plates of ivory, the figures of the animals being at times cut fully in the round and found in the lowest strata of the cares, umler many feet of eare earth and stalagma, and associaterl with the bones of a quaternary and, at times, an arctic fauna. The similarity of much of this eave work with much of the Eskimo production of the present day has given rise to innumeral, le theories concerning a common origin for both people.

The carrings of wood and stone of the Ilupa Indians, the little stone and lone figures of the Pueblo Indians, and the wonderfully carverl pipes of the eastern North Ameriean Indians show a skill in carving possesserl by a race who knew nothing of sculpture. The earrings of Mexico were above the orlinary, as is evirlencerl by the reputed skill with which the emeralds of Cortez were carverl and the known exellenee of Mexican carrings of cuartz erystal, of jadeite, and of olsiclian. To see them is to be convincer that those whrn marle them were thoroughly conversant with the fracture of minerals. ('arvings and scullptures, if any number be examined and carefully (omprared one with another. aplear to have been producerl in a sinvilar manner, no matter what their origin or their age, whether from Fiji or the French caves. If the material lue haril and tough, a stone 
tool batters it into shape; softer material is workel according to its texture. One may be cut, another scraped, or it may be that the saw is found most useful; but whatever method has been employed, it will be seen that it was the one best suited to the material.

The crude hand tool gave way to one with a handle, and in time its working capacity was increased by means of water, air, or electric power.

To attain an appreciation of the sculptor's art, at all thorough, would necessitate a study of the monuments of Egypt, the rock temples of India, the façades of the wonderful palaces of Camhorlia and of Central and South America, as well as of the subterranean galleries of those countries.

With the Greeks the tool and the stone combined and made perfection first possible. To improve upon it would necessitate an improred tool and better material. It appears to have stood the test of two thousand five hunched years at least.

Ellicott City, Maryland. 



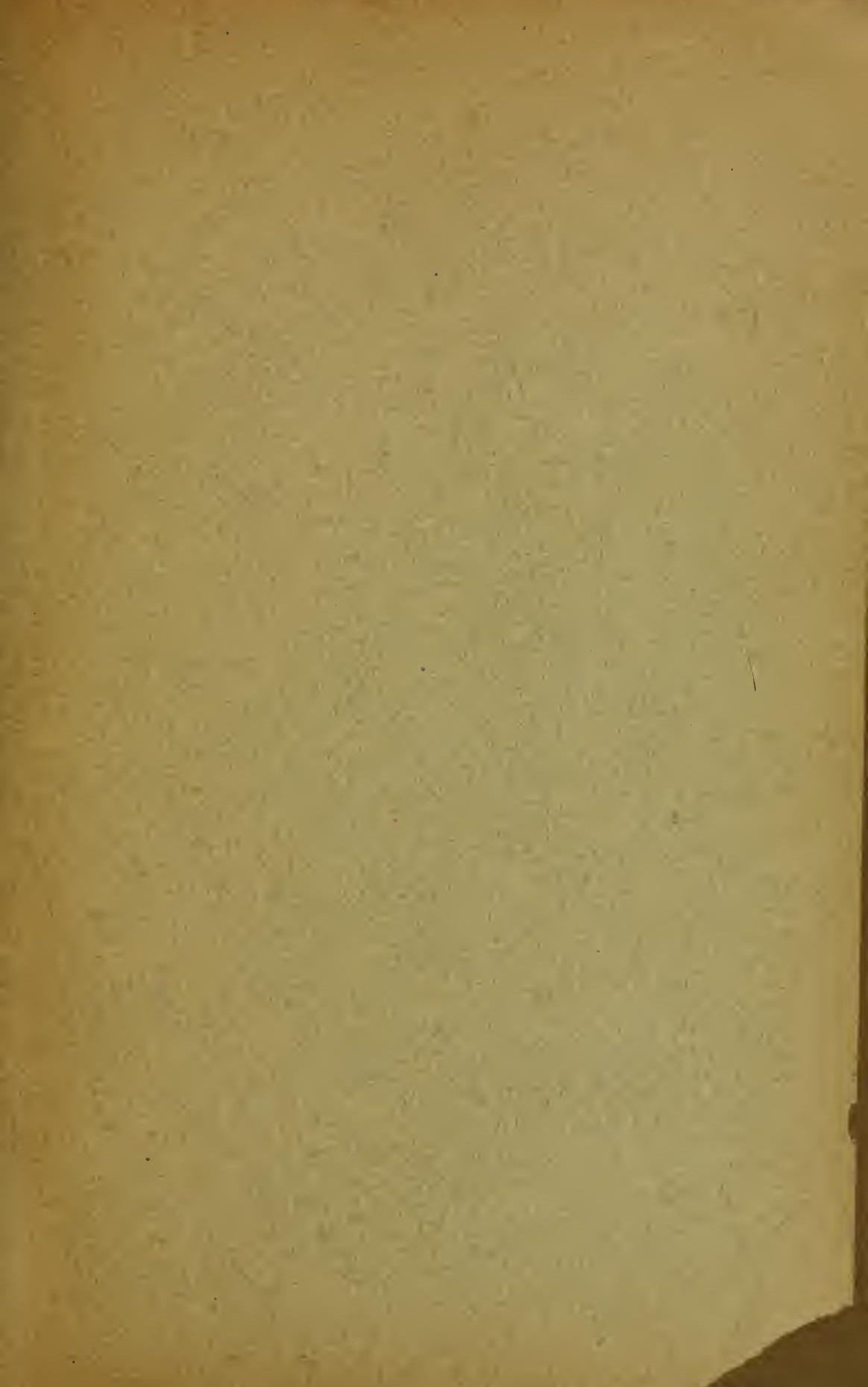





\section{Photomount}

Pamphlet

Einder

Gaylord Bros.

Makers

Syracusc, N. Y.

PAT. JAN 21, 1908 
SMITHSONIAN INSTITUTION LIBRARIES 